\title{
Dermoid Cyst of the Skin
}

National Cancer Institute

\section{Source}

National Cancer Institute. Dermoid Cyst of the Skin. NCI Thesaurus. Code C4632.

A benign hamartomatous tumor that possesses various epidermal derivatives and is due to sequestration of skin along the lines of embryonic closure. 